\title{
Alterations in the Activity of Spinal and Thalamic Opioid Systems in a Mice Neuropathic Pain Model
}

\author{
Ewelina Rojewska, ${ }^{a}$ Agnieszka Wawrzczak-Bargiela, ${ }^{\mathrm{b}}$ Edina Szucs, ${ }^{\mathrm{c}}$ Sandor Benyhe, ${ }^{\mathrm{c}}$ Joanna Starnowska, ${ }^{\mathrm{a}}$ \\ Joanna Mika, ${ }^{a}$ Ryszard Przewlocki ${ }^{\mathrm{b}}$ and Barbara Przewlocka ${ }^{\mathrm{a} *}$ \\ ${ }^{a}$ Department of Pain Pharmacology, Institute of Pharmacology, Polish Academy of Sciences, 12 Smętna Street, 31-343 Krakow, Poland \\ ${ }^{\mathrm{b}}$ Department of Molecular Neuropharmacology, Institute of Pharmacology, Polish Academy of Sciences, 12 Smętna Street, 31-343 Krakow, Poland \\ ${ }^{c}$ Institute of Biochemistry, Biological Research Center, Hungarian Academy of Sciences, Temesvarikrt 62 Street, Szeged 6726, Hungary
}

\begin{abstract}
Clinical studies have reported lower effectivity of opioid drugs in therapy of neuropathic pain. Therefore, to determine the changes in endogenous opioid systems in this pain more precisely, we have studied the changes in the pain-related behavior on days 1,14 , and 28 following a chronic constriction injury (CCl) to the sciatic nerve in mice. In parallel, we have studied the changes of -(MOP), -(DOP) and -(KOP) receptors, proenkephalin (PENK) and prodynorphin (PDYN) mRNA levels, as well as GTP $\gamma \mathrm{S}$ binding of opioid receptors on the ipsi- and contralateral parts of the spinal cord and thalamus on the 14th day following $\mathrm{CCl}$, as on this day the greatest manifestation of pain-related behavior was observed. On ipsilateral spinal cord, the decrease in MOP/DOP/KOP receptor and increase in PDYN/PENK mRNA expression was observed. In thalamus, MOP/DOP/KOP receptor expression decreased contralaterally. On ipsilateral side, there were no changes in PDYN/PENK or DOP/KOP receptor expression, but MOP mRNA decreased. The spinal GTP $\gamma$ S binding of MOP/DOP/KOP receptor ligands decreased on the ipsilateral side, yet the effect was less pronounced for DOP receptor ligands. In thalamus, a decrease was observed on the contralateral side for all opioid receptor ligands, especially for DOP ligand. A less pronounced decrease in GTP $\gamma$ S binding of spinal DOP ligands may indicate a weaker stimulation of ascending nociceptive pathways, which could explain the absence of decreased activity of DOP receptor ligands in neuropathy. These findings may suggest that drugs with a higher affinity for the DOP receptor will perform better in neuropathic pain. $\odot 2018$ Published by Elsevier Ltd on behalf of IBRO.
\end{abstract}

Key words: chronic constriction injury, neuropathic pain, opioid peptides, opioid receptors.

\section{INTRODUCTION}

Neuropathic pain tends to be less opioid responsive than nociceptive pain, and opioids are only partially effective in preclinical models of neuropathic pain, and this phenomenon is not fully understood. The analgesic properties of opioid drugs in neuropathic pain may depend on molecular changes in endogenous opioid systems that contribute to the development and maintenance of this type of pain by weaker counteracting pain stimulation. Any nerve tissue injury leads to endogenous changes on the molecular and systemic levels, with antinociceptive systems being rapidly activated just after injury, and losing their initial analgesic efficacy shortly after. The widespread

\footnotetext{
${ }^{*}$ Corresponding author. Address: Institute of Pharmacology, Polish Academy of Sciences, Department of Pain Pharmacology, 12 Smetna Str., 31-343 Cracow, Poland. Fax: + 48-12-6374500. E-mail address: przebar@if-pan.krakow.pl (B. Przewlocka). Abbreviations: $\mathrm{CCl}$, chronic constriction injury; EGTA, ethylene glycol-

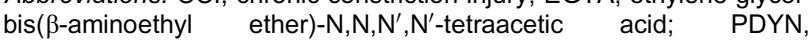
prodynorphin; PENK, proenkephalin.
}

changes, including intensified release of pronociceptive molecules, counteract the action of exogenous opioids; this, with weakened efficacy of endogenous antinociceptive systems themselves, contributes to unsatisfying analgesic effect of opioid drugs, which are eventually far less efficient in neuropathic pain than in nociceptive pain. It has been shown in a number of studies that the activity of endogenous opioid peptides is changed by nociceptive and chronic painful stimuli; the increase in endogenous opioid peptide release consequently enhances opioid receptor occupancy. This effect has been documented in animal and human studies (Albe-Fessard et al., 1985; ladarola et al., 1988; Zangen et al., 1998; Zubieta et al., 2001; Bencherif et al., 2002; Obara et al., 2009; Mika et al., 2014; Popiolek-Barczyk et al., 2014). Neuropathic pain is associated with significant changes in spinal and thalamic neuronal activity and sensitization of the neural structures involved in pain perception (Patel and Dickenson, 2016; Sandkuler et al., 2011), which may play a key role in the persistent experience of neuropathic pain in humans. 
Changes characteristic of neuropathic pain may also be induced in animal models (Henderson et al., 2013). Opioid peptides and their receptors are normally involved in mechanisms blocking out pain, and their functional and biochemical alterations appear to display a critical role in the development and maintenance of neuropathic pain.

Our previous studies have shown a decrease in the expression of opioid receptors in the ipsilateral part of the spinal cord and DRG in rat and mouse models of neuropathy (Obara et al., 2009; Mika et al., 2014; Popiolek-Barczyk et al., 2014). Interestingly, in patients suffering from chronic central pain, a positron-emission tomography study has shown a decrease in opioid [ ${ }^{11 \mathrm{C}}$ ] diprenorphine binding in the thalamus contralaterally to the painful side (Maarrawi et al., 2007b). This study was however, limited only to the MOP receptor; but because opioids have different affinities for opioid receptors, it is important to know which receptor profile of the opioid drug is the most suitable for the treatment of neuropathy. And therefore, studying changes in individual types of opioid receptors may help indicate such a drug.

An injury of a nervous tissue leads to complex changes in ascending tracts, from peripheral nervous system, through spinal cord, to brain structures. Our aim was to verify whether inflicting an injury just on one site of the nervous system would cause uni- or bilateral changes, and whether the changes are similar in the spinal cord and in the brain tracts. That is why we focused on the issue, as it could potentially explain some aspects of neuropathic pain development and opioid drugs action. Recently, asymmetry in different functions in the brain in neuropathic pain has been suggested (Leite-Almeida et al., 2014), and this problem needs to be addressed more extensively in animal neuropathic pain models. Obara et al. (2010) demonstrated that differences in the pharmacological effectiveness of different opioid receptor ligands with peptide and nonpeptide chemical structures in neuropathic pain could result from functional changes in the -(MOP) receptor in the spinal cord and DRG in a chronic constriction injury $(\mathrm{CCl})$ rat model and Narita et al. (2002) have demonstrated that nerve injury leads to a decrease in MOP receptormediated G-protein activation in the spinal cord and in the brain. Little is known, however, about the functional alterations of KOP and DOP receptors in the nociceptive pathways upon neuropathic pain. This is of particular interest, since opioids with particular (differential) selectivity for opioid receptor types may be more suited for treatment of neuropathic pain. In our current research we have used besides MOP-, -(DOP) and -(KOP) mRNA level, the selective opioid receptor ligand-stimulated guanosine-50o-(3-thio) triphosphate (GTP $\gamma \mathrm{S}$ ) binding to measure the activation of $\mathrm{G}$-proteins. This method characterizes the functional state of the receptor and provides convenient measures of opioid receptor activity close to the receptor in the signaling cascade. The results presented in this paper extend earlier observations (Zhang et al., 1998; Xiao et al., 2008; Obara et al., 2009) and provide additional impact on our understanding of the mechanisms of reduced antinociceptive effectiveness of opioids under neuropathic pain conditions.
Therefore, in the present paper, we analyzed neuropathic pain-related behavioral changes estimated 1,14 , and 28 days after sciatic nerve injury. In parallel, we have studied the changes of MOP, DOP and KOP receptors, proenkephalin (PENK) and prodynorphin (PDYN) mRNA levels, as well as GTP $\gamma \mathrm{S}$ binding of opioid receptors on the ipsi- and contralateral parts of the spinal cord and thalamus on the 14th day following $\mathrm{CCl}$, as on this day the most pronounced behavioral changes were observed.

\section{EXPERIMENTAL PROCEDURES}

\section{Animals}

Adult male Albino-Swiss CD-1 mice (Charles River, Germany; 20-25 g) were used in this study. Animals were housed in groups of six in cages with sawdust bedding under a standard $12 \mathrm{~h} / 12 \mathrm{~h}$ light/dark cycle (lights on at 06.00 a.m.); food and water were available ad libitum. All experiments were carried out according to the recommendations of International Association for the Study of Pain (Zimmermann, 1983) and the NIH Guide for Care and Use of Laboratory Animals and were approved by the Local Bioethics Committee (Krakow, Poland, permission numbers 1214/2015).

\section{Chronic constriction injury $(\mathrm{CCl})$}

The $\mathrm{CCl}$ model was performed according to Bennett and Xie (1988). The surgical procedure was performed under isoflurane anesthesia. Briefly, an incision was made below the right hipbone, parallel to the sciatic nerve. The sciatic nerve was exposed, and three ligatures $(4 / 0$ silk) were tied loosely around the nerve distal to the sciatic notch with 1-mm spacing, until a brief twitch in the respective hind limb was observed. After $\mathrm{CCl}$, all mice developed tactile/thermal hypersensitivity. The mice with sciatic nerve injury will be referred to by the abbreviation " $\mathrm{CCl}$ mice" throughout the text of the manuscript. The behavioral experiments were conducted on the 1st, 14th and 28th day following the $\mathrm{CCl}$ surgical procedure. Biochemical experiments were conducted on the 14th day after injury, the day of major changes in response to thermal and mechanical stimuli.

\section{Behavioral tests}

Von Frey's test. Mechanical tactile hypersensitivity in $\mathrm{CCl}$ mice was measured on the 1st, 14th and 28th day after $\mathrm{CCl}$ using a series of von Frey filaments (Stoelting, Wood Dale, IL, USA), ranging from 0.6 to $6 \mathrm{~g}$ (Mika et al., 2015). Animals were placed in plastic cages with a wire-mesh floor, allowing them to move freely. They were allowed to acclimate to this environment for approximately 5-15 min prior to testing. The von Frey filaments were applied in ascending order to the midplantar surface of the both hind paw through the mesh floor. Each probe was applied to the foot until it started to bend. The ipsilateral and contralateral paws in $\mathrm{CCl}$ mice (or both hind paws in naïve mice) were tested $2-3$ times and a mean 
value was calculated. The time interval between consecutive applications of filaments was at least $5 \mathrm{~s}$.

Cold plate test. Sensitivity to noxious thermal stimuli was assessed on the 1st, 14th and 28th day after $\mathrm{CCl}$ using a Cold/Hot Plate Analgesia Meter from Columbus Instruments. The latency was defined as the amount of time it took for the hind paw to begin to shake after the mouse was placed on a cold plate $\left(2^{\circ} \mathrm{C}\right)$. In $\mathrm{CCl}$ mice, the injured paw reacted first in all cases. The ipsilateral paw reaction was noted first and then the contralateral paw response was awaited and noted. In naive mice the reaction of any hind paw was noted. The cut-off latency for this test was $30 \mathrm{~s}$ (Mika et al., 2015).

\section{Biochemical study}

qRT-PCR analysis. RNA extraction and complementary DNA (cDNA) synthesis. On day 14 after $\mathrm{CCl}$, when the most pronounced changes in response to thermal and mechanical stimuli were observed, the mice were decapitated. Immediately after decapitation the spinal cord was removed using hydraulic pressure and the brain was dissected from the skull. Tissue was collected on ice-cold plate. Spinal cord lumbar fragments (L4-L6) were divided for ipsi- and contralateral parts. The thalamus was dissected according to Palkovits and Brownstein (1987). At first the hypothalamus, cerebellum, cortex hippocampus and mesencephalon tissues were dissected. Finally the thalamus was dissected from the rest of remaining tissue and divided on ipsi- and contralateral parts to the site of sciatic nerve injury.

Total RNA was extracted according to the method described by Chomczynski and Sacchi (1987) using TRIzol reagent (Invitrogen) as previously described (Rojewska et al., 2016). The tissue samples were placed in individual tubes containing the tissue storage reagent RNA later (Ambion Inc.) and were stored at $-70{ }^{\circ} \mathrm{C}$ for RNA isolation. For cDNA synthesis, $1000 \mathrm{ng}$ of total RNA was reverse transcribed using an Omniscript RT Kit (Qiagen) with oligo(dT) primer (Fermentas) in a total reaction volume of $20 \mu \mathrm{l}$. The cDNA was diluted 1:10 with $\mathrm{H} 2 \mathrm{O}$, and for each reaction, approximately $50 \mathrm{ng}$ of cDNA synthesized from the total RNA template was obtained from each individual animal and used for quantitative real-time polymerase chain reaction (qRT-PCR). qRTPCR was performed using Assay-On-Demand TaqMan probes (Applied Biosystems, USA) and run on a RealTime PCR iCycler (Bio-Rad, Hercules, CA, USA). The amplification efficiency for each assay was determined by running a standard dilution curve. The following TaqMan primers were used: rat hypoxanthine guanine phosphoribosyltransferase, (Mm03024075_m1; HPRT1), PDYN (Mm00457573_m1; Pdyn); preproenkephalin (Mm01212875_m1; Penk); opioid receptor, mu 1 (Mm01188089_m1; Oprm1, MOP); opioid receptor, delta 1 (Mm01180757_m1; Oprd1, DOP); and opioid receptor, kappa 1 (Mm01230885_m1; Oprk1, KOP). The Hprt levels did not significantly differ across all groups, and Hprt was, therefore, used as a housekeeping gene control (data not shown). The cycle threshold values were calculated automatically with the iCycler IQ 3.0 software using the default parameters. The RNA abundance was calculated as $2-$ (threshold cycle).

\section{GTP $\gamma$ S functional binding assay}

Chemicals. The highly selective MOP receptor agonist enkephalin analog Tyr-D-Ala-Gly-(NMe)Phe-Gly-ol (DAMGO) and the KOP receptor agonist peptide dynorphin $_{1-13}$ were obtained from Bachem Holding AG (Bubendorf, Switzerland). The structurally modified DOP receptor-specific deltorphin II derivative, $\| \mathrm{e}^{5,6}$ deltorphin II (Tyr-D-Ala-Phe-Gly-lle-lle-Gly-NH2) was synthesized in the Laboratory of Chemical Biology of the Biological Research Centre (BRC, Szeged, Hungary). Each ligand was dissolved in tri distilled water and stored in $1 \mathrm{mM}$ stock solution at $-20^{\circ} \mathrm{C}$. EGTA, $\mathrm{MgCl}_{2} \times 6 \mathrm{H}_{2} \mathrm{O}, \mathrm{NaCl}$, Tris- $\mathrm{HCl}$, guanosine $5^{\prime}$-diphosphate sodium salt (GDP) and guanosine $5^{\prime}-\mathrm{O}-[\gamma$-thio]triphosphate salt (GTP $\gamma \mathrm{S}$ ) were purchased from Sigma-Aldrich (Budapest, Hungary). The radiolabeled GTP analog ${ }^{\left[{ }^{35 S}\right]} \mathrm{GTP} \gamma \mathrm{S}$ (specific activity: $3.7 \times 1013 \mathrm{~Bq} / \mathrm{mmol} ; 1000 \mathrm{Ci} / \mathrm{mol}$ ) was obtained from Hartmann Analytic (Braunschweig, Germany). The Ultima GoldTM MV harmless scintillation cocktail was purchased from Perkin Elmer.

GTP $\gamma S$ binding. Mouse spinal cord and thalamus for G-protein binding assays were collected only on day 14 after $\mathrm{CCl}$, when the most pronounced changes in response to thermal and mechanical stimuli were observed. The structures were prepared as described for the mRNA assay in the section above. The crude membrane fractions of mouse spinal cord and thalamus were used for ${ }^{\left[{ }^{35 S}\right]}$ GTP $\gamma S$ binding experiments after being prepared as described earlier (Szücs et al, 2016). Briefly, the thawed and ice-cooled spinal cord and thalamus were homogenized on ice in ten volume $(10 \mathrm{ml}$ buffer/g original tissue) ice-cold TEM buffer (50 mM Tris$\mathrm{HCl}, 1 \mathrm{mM}$ EGTA, $5 \mathrm{mM} \mathrm{MgCl}$, $\mathrm{pH}$ 7.4). Protein concentrations were determined by the Bradford method (Bradford, 1976) and were approximately 4-6 mg/ml. Membrane samples were then aliquoted into the Eppendorf tubes containing between 50 and $60 \mu$ of membrane suspensions and stored at $-80^{\circ} \mathrm{C}$ until further processing.

Opioid ligand-stimulated $G T P \gamma S$ functional binding assay. In GTP $\gamma \mathrm{S}$ binding experiments, the GDP $\gamma$-GTP exchange of the Gai/o proteins was measured in the presence of the ligands to determine their potency and the maximal efficacy of the activated G-proteins. The functional ${ }^{\left[{ }^{[5 S}\right]} \mathrm{GTP} \gamma \mathrm{S}$ binding experiments were performed as previously described (Traynor and Nahorski, 1995). Briefly, the membrane proteins $(\sim 10 \mu \mathrm{g} / \mathrm{ml})$ were incubated at $30^{\circ} \mathrm{C}$ for $60 \mathrm{~min}$ with ${ }^{[35 \mathrm{~S}]}$. GTP $\gamma \mathrm{S}\left(20 \mathrm{MBq} / 0.05 \mathrm{~cm}^{3} ; 0.05 \mathrm{nM}\right)$ and increasing concentrations $\left(10^{-10}-10^{-5} \mathrm{M}\right)$ of DAMGO in Tris-EGTA buffer ( $\mathrm{pH}$ 7.4) containing $30 \mu \mathrm{M}$ GDP, $1 \mathrm{mM}$ EGTA, $5 \mathrm{mM} \mathrm{MgCl}_{2}, 100 \mathrm{mM} \mathrm{NaCl}$ and $50 \mathrm{mM}$ Tris- $\mathrm{HCl}$ in a final volume of $1 \mathrm{ml} /$ reaction tube. Nonspecific binding was 
determined with $10 \mu \mathrm{M}$ of unlabeled GTP $\gamma \mathrm{S}$ and subtracted from the total binding. Basal activity (defined as $100 \%$ ) indicates constitutive G-protein activity levels in the absence of any stimulating ligand. Bound and free ${ }^{\left[{ }^{35 S}\right]}$ GTP $\gamma$ S were separated by vacuum (Brandel M24R Cell Harvester) filtration through the Whatman GF/B glass fiber filters and washed three times with $5 \mathrm{ml}$ of ice-cold $50 \mathrm{mM}$ Tris- $\mathrm{HCl}(\mathrm{pH} \mathrm{7.4)}$ buffer. The analyses were performed in triplicate and repeated at least three times.

Increasing concentrations of the ligands produced dose-dependent stimulation of ${ }^{\left[{ }^{35 S}\right]} \mathrm{GTP} \gamma \mathrm{S}$ binding in each sample. High activation of $\mathrm{G}$-proteins in MOP (DAMGO) and KOP (dynorphin ${ }_{1-13}$ ) receptors were observed in the spinal cord and thalamus of naive animals on both the contralateral and ipsilateral sides. Moderate stimulations by $\mathrm{Il} \mathrm{e}^{5,6}$ deltorphin II were found in the spinal cord and thalamus for the DOP receptor.

\section{Data analysis}

The behavioral data are presented as mean \pm S.E.M. of 9-15 mice per group. Inter-group differences were analyzed by ANOVA followed Bonferroni's multiple comparison test. Significance was defined as ${ }^{\star * \star} p<0.001$ indicating a significant difference compared with the control (naive) animals; ${ }^{\circ 00} p<0.001$ indicating a significant difference compared with the contralateral side.

The qRT-PCR data are presented as the fold change of the controls, which represents normalized averages derived from the threshold cycles in qPCR and from 4 to 10 samples per group. Inter-group differences were analyzed by Bonferroni's multiple comparison test. Significance was defined as ${ }^{*} p<0.05,{ }^{* *} p<0.01$ indicating a significant difference compared with the control (naive) animals. All graphs were prepared using GraphPad Prism 7.0.

Data analysis of GTP $\gamma S$ binding was performed with GraphPad Prism 5.0 software (GraphPad Prism Software Inc., San Diego, CA, USA). Non-linear regression analysis of the ligand-stimulated $\left[{ }^{35} \mathrm{~S}\right] \mathrm{GTP} \gamma \mathrm{S}$ binding assays used the 'sigmoidal dose-response' fitting to determine the maximal stimulation or efficacy $\left(E_{\max }\right)$ of the receptors' G-protein and ligand potency $\left(E C_{50}\right)$. Stimulation is represented as a percent of the specific ${ }^{35}$ S]GTP $\gamma S$ binding observed above the basal activity level (taken to be $100 \%$ ). Unpaired $t$-tests with two-tailed $P$-values were performed to determine significance using GraphPad Prism 5.0.

\section{RESULTS}

Time-course changes in sensitivity to mechanical and thermal stimuli as measured in naïve mice and 1, 14 and 28 days after injury in $\mathrm{CCl}$ mice

Pain thresholds in response to mechanical and thermal stimuli were measured by the von Frey and cold plate tests, respectively. No changes in the response to both types of stimuli were observed on the contralateral paw at the time points examined (Fig. 1A, B) as compared to

\section{Behavioral tests}

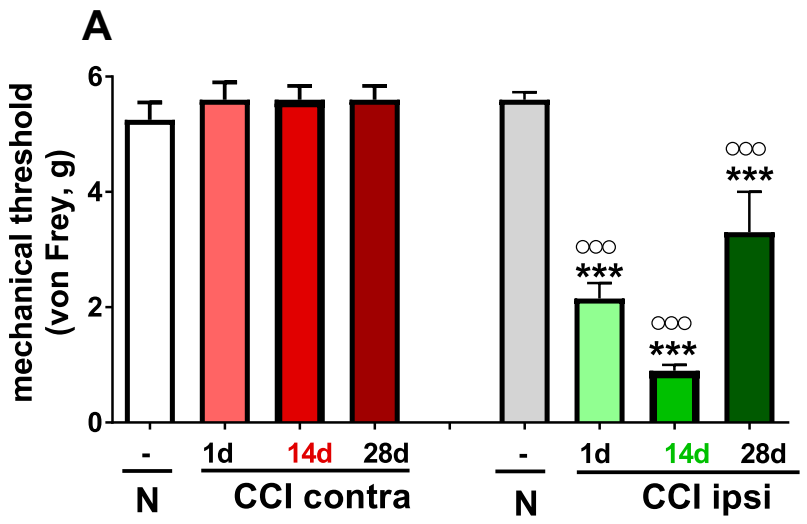

B

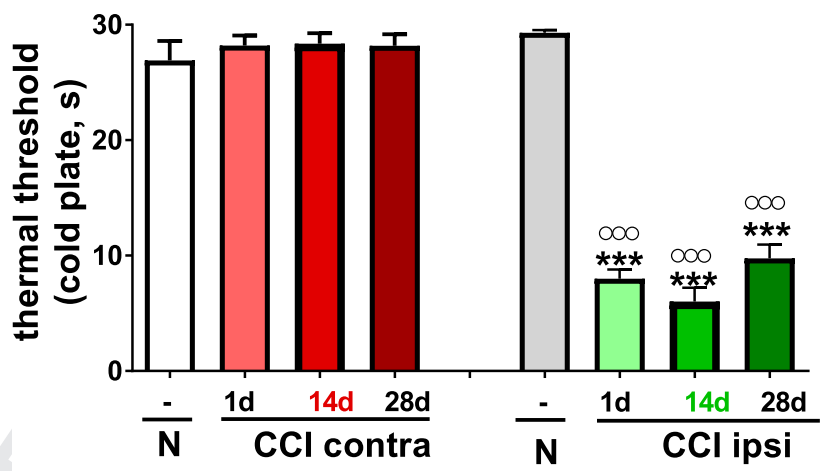

Fig. 1. The level of mechanical (A; von Frey test) and thermal (B; cold plate test) hypersensitivity measured in naïve $(\mathrm{N})$ and 1,14 and 28 days after injury in $\mathrm{CCl}$ mice. The data are presented as mean \pm S.E.M. (9-15 mice per group). Intergroup differences were analyzed using Bonferroni's multiple comparison tests. ${ }^{\star \star \star} p<0.001$ indicates a significant difference compared with the control (naive) animals; ${ }^{000} p<0.001$ indicates a significant difference compared with the contralateral side on the respective day after $\mathrm{CCl}$.

naïve mice. In contrast, response times on the ipsilateral side of the injury were significantly reduced starting from the very first day after $\mathrm{CCl}$. The lowest pain threshold in the von Frey test was observed on day 14. On day 28 , the threshold reached values closest to the level of controls, although there was still an observable significant decrease in the pain threshold (Fig. 1A). The response time to thermal stimuli was also significantly reduced at all measured time points. Differences between time points were not large, yet the strongest effect was observed on day 14 after nerve injury (Fig. 1B).

The level of opioid receptors' mRNA in the spinal cord and thalamus measured in naïve mice and 14 days after injury in $\mathrm{CCl}$ mice

The levels of MOP, DOP and KOP opioid receptor mRNA in the spinal cord in $\mathrm{CCl}$ mice were not changed on the contralateral side in comparison with naïve mice. On the ipsilateral side, mRNA level of all types of opioid 


\section{SPINAL CORD}
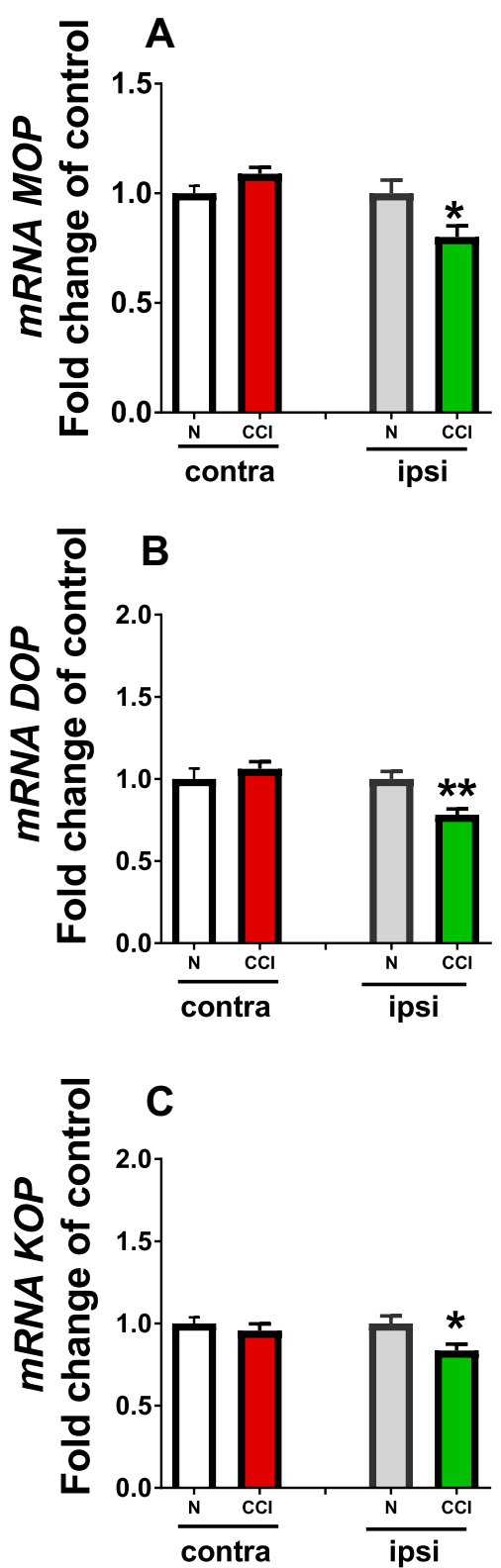

THALAMUS
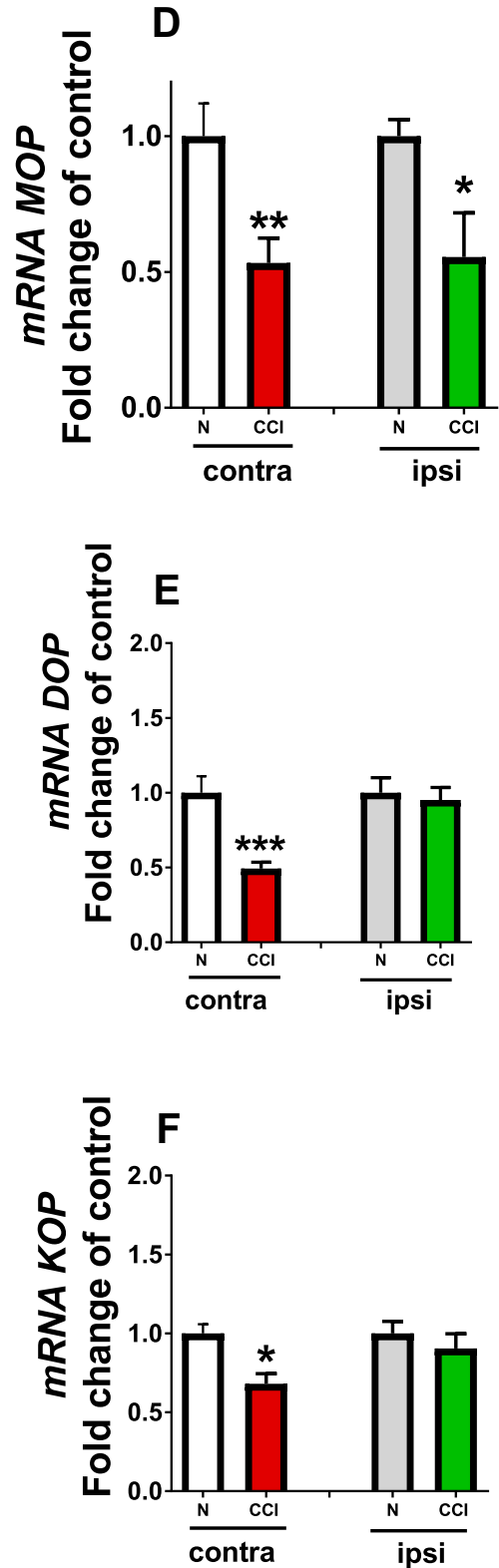

Fig. 2. $q R T-P C R$ analysis of the MOP DOP and KOP mRNA levels in the both sides in naïve mice $(N)$ and ipsi- and contralateral parts of the spinal cord (A-C) and thalamus (D-F) 14 days after injury in $\mathrm{CCl}$ mice. The data are presented as mean \pm S.E.M., which represent normalized averages derived from the threshold cycles obtained from qRT-PCR of 4-8 samples per group. ${ }^{*} p<0.05,{ }^{* *} p<0.01$ and ${ }^{* * *} p<0.001$ indicates a significant difference compared with the naive animals.

receptors significantly decreased in the spinal cord (Fig. 2A-C). The level of MOP, DOP and KOP receptor mRNA in the thalamus was reduced significantly on the contralateral side in comparison with naïve mice. On the ipsilateral side of the thalamus, only mRNA of MOP receptor decreased (Fig. 2D). The levels of mRNA for the DOP and KOP receptors did not change on the ipsilateral side (Fig. 2E, F).
Dose-dependent stimulation of GTP $\gamma$ S binding produced by selective ligands of opioid receptors in the spinal cord and thalamus measured in naïve mice and 14 days after injury in $\mathrm{CCl}$ mice

The observed decreases in maximal stimulation $\left(E_{\max }\right)$ values in membranes prepared from naive animals were not significant in any case. The samples from $\mathrm{CCl}$-exposed mice showed a difference in G-protein activity when comparing contra- and ipsilateral sides. The maximal stimulation was significantly lower on the ipsilateral side in the spinal cord, while a decrease was observed on the contralateral side in the thalamus for all three types of opioid receptors (Table 1).

Significant differences between contra- and ipsilateral sides were found in $\mathrm{CCl}$-exposed mice for MOP receptors in the spinal cord $\left({ }^{* * *} P=0.0007\right.$; two-tailed $P$-value, $t=9.594, \quad \mathrm{df}=4)$ and in the thalamus $\left({ }^{* *} P=0.0019\right.$; two-tailed $P$-value, $\quad t=7.306, \quad \mathrm{df}=4) . \quad$ A significant difference in G-protein activation was observed when comparing the contralateral and ipsilateral sides of $\mathrm{CCl}$-exposed animals for DOP receptors in the spinal cord ( ${ }^{* *} P=0.0031 ;$ two-tailed $P$-value, $\left.t=6.402, \quad \mathrm{df}=4\right)$ and in the thalamus $\left({ }^{*} P=0.0228\right.$; two-tailed $P$-value, $t=3.598, \mathrm{df}=4$ ). The effect was statistically significant between the contralateral and ipsilateral sides of the spinal cord ${ }^{* *} P=0.0012$; two-tailed $P$-value, $t=8.284$, 


\section{SPINAL CORD}

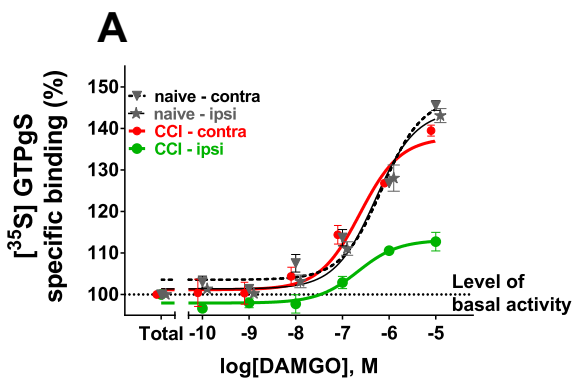

B

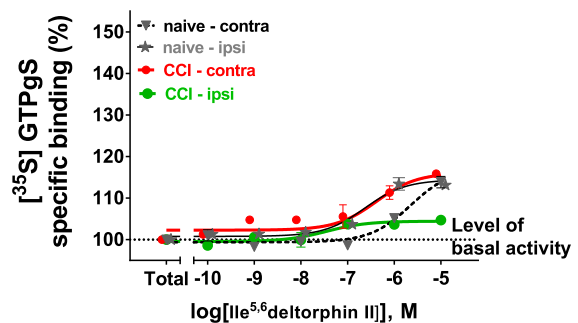

C

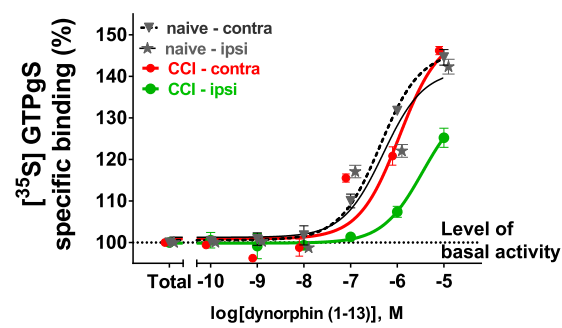

THALAMUS

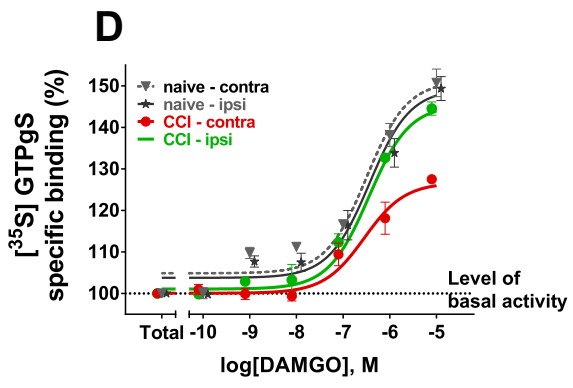

E
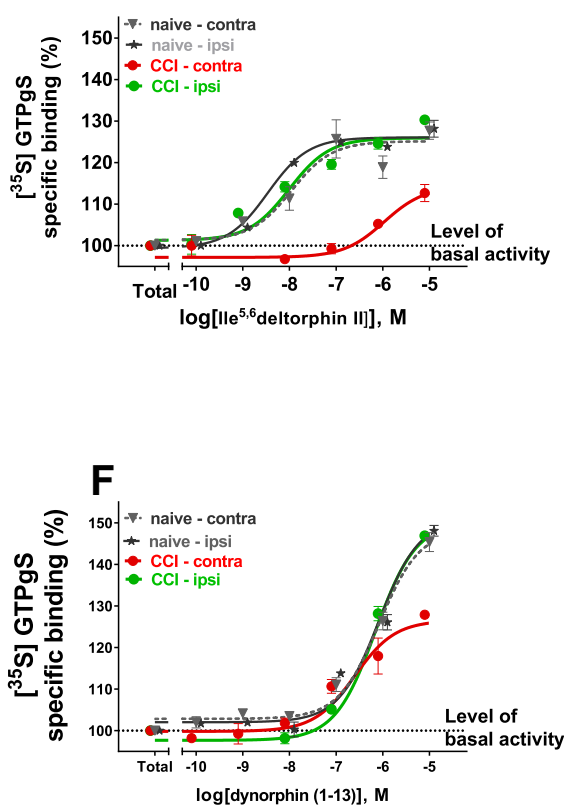

Fig. 3. qRT-PCR analysis of the PDYN $(A, C)$ and PENK (B, D) mRNA levels in naïve mice $(N)$ and in the ipsi- and contralateral spinal cord (A, B) and thalamus (C, D) 14 days after injury in CCl mice. The data are presented as mean \pm S.E.M., which represent normalized averages derived from the threshold cycles obtained from qRT-PCR of $6-10$ samples per group. ${ }^{\star} p<0.05,{ }^{\star *} p<0.01$ indicates a significant difference compared with the naïve animals.

$\mathrm{df}=4) \quad$ and thalamus $\left(^{\star *} P=0.0011\right.$; two-tailed $P$-value, $t=8.362, \mathrm{df}=4)$ in CCl-exposed mice for KOP receptors (Table 1).

The GTP $\gamma \mathrm{S}$ binding stimulated by DAMGO, selective peptide agonist of the MOP-receptor, was similar in naïve mice (both parts) and the contralateral part of the spinal cord in $\mathrm{CCl}$-subjected mice, yet it was much weaker on the ipsilateral part of CCl-subjected mice (Fig. 4A). The GTP $\gamma \mathrm{S}$ binding stimulated by Ile $\mathrm{e}^{5,6}$ deltorphin II was very low but similar between both parts in naïve mice and contra part of the spinal cord in $\mathrm{CCl}$ mice, while being slightly weaker in the ipsilateral part of the spinal cord in $\mathrm{CCl}$ mice (Fig. 4B). The GTP $\gamma \mathrm{S}$ binding stimulated by dynorphin ${ }_{1-}$ 13 was similar in naïve mice (both parts) and on the contralateral part of the spinal cord in $\mathrm{CCl}$ mice, but it was much weaker in the ipsilateral part of the spinal cord in $\mathrm{CCl}$ mice (Fig. 4C).

In the thalamus, the GTP $\gamma \mathrm{S}$ binding stimulated by the MOP receptor selective peptide agonist ligand DAMGO was similar in naïve mice (both parts) and the ipsilateral part in $\mathrm{CCl}$ mice but was much weaker on the contralateral part of $\mathrm{CCl}$ mice (Fig. 4D). The GTP $\gamma S$ binding stimulated by $\| \mathrm{e}^{5,6}$ deltorphin II was very low but similar between both parts of the thalamus in naïve mice and ipsilateral parts in $\mathrm{CCl}$ mice, while significantly weaker stimulation was observed
417

418

419

420

421

422

423

424

425

426

427

428

429

430

431

432

433

434

435

436

437

438

439

440

44

442

443

444

445

446

447

448

449

450

451

452

453

454

455

456

457

458 459

Table 1. G-protein activation by the selective opioid peptide receptor agonists DAMGO, $\|^{5,6}$ deltorphin II and dynorphin $_{1-13}$ in the spinal cord and thalamic membrane preparations of naive and $\mathrm{CCl}$ mice on the contra- and ipsilateral sides

\begin{tabular}{|c|c|c|c|c|c|}
\hline \multicolumn{6}{|c|}{ Maximal stimulation (efficacy) $-E_{\max } \pm$ S.E.M. (\%) } \\
\hline \multirow[t]{2}{*}{ Receptor } & & \multicolumn{2}{|l|}{ Spinal cord } & \multicolumn{2}{|l|}{ Thalamus } \\
\hline & & Contra & Ipsi & Contra & Ipsi \\
\hline \multirow[t]{2}{*}{ MOP } & Naive & $147.5 \pm 2.8$ & $144.4 \pm 2.1^{\mathrm{NS}}$ & $151.1 \pm 3.0$ & $149.3 \pm 3.2^{\mathrm{NS}}$ \\
\hline & $\mathrm{CCl}$ & $137.0 \pm 2.1$ & $113.1 \pm 1.3^{* \star \star}$ & $126.7 \pm 2.1$ & $145.5 \pm 1.5^{\star *}$ \\
\hline \multirow[t]{2}{*}{ DOP } & Naive & $117.3 \pm 2.1$ & $114.4 \pm 1.0^{\mathrm{NS}}$ & $125.1 \pm 1.7$ & $126.1 \pm 0.7^{\mathrm{NS}}$ \\
\hline & $\mathrm{CCl}$ & $116.1 \pm 1.7$ & $104.4 \pm 0.6^{* *}$ & $114.3 \pm 2.9$ & $125.9 \pm 1.3^{*}$ \\
\hline \multirow[t]{2}{*}{ KOP } & Naive & $146.1 \pm 1.6$ & $141.6 \pm 3.6^{\mathrm{NS}}$ & $148.4 \pm 2.3$ & $151.1 \pm 2.8^{\mathrm{NS}}$ \\
\hline & $\mathrm{CCl}$ & $146.2 \pm 1.0$ & $125.2 \pm 2.3^{* \star}$ & $126.5 \pm 2.2$ & $150.2 \pm 1.8^{* \star}$ \\
\hline
\end{tabular}

Experimental data were processed by GraphPad Prism 5.0 using the sigmoid fit option of the dose-response curves. NS: not significant; ${ }^{*} p<0.05$, “* $p<0.01$ and $p<0.001$ based on unpaired $t$-tests. 
SPINAL CORD
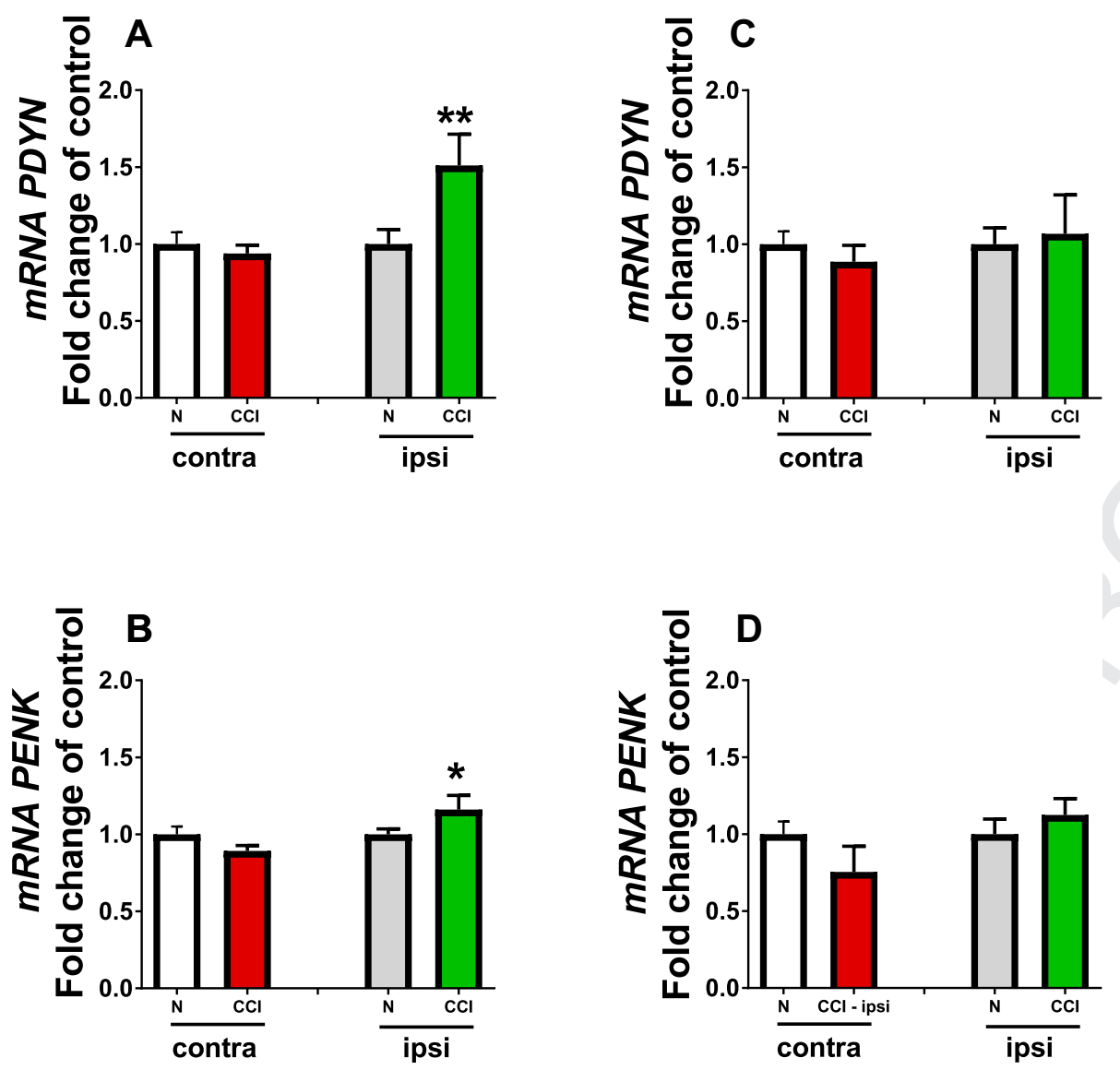

Fig. 4. Opioid receptor signaling mediated by specific ligands in membranes prepared from spinal cord and thalamus of naïve and $\mathrm{CCl}$ mice in ipsi- and contralateral side. The maximal efficacy $\left(E_{\max }\right)$ above the basal activity of MOP, DOP and KOP receptors in stimulating G-proteins in the spinal cord $(A-C)$ and thalamus (D-F). Percent increases (\%) in the specifically bound radiolabeled nucleotide $\left[{ }^{35}\right.$ S ]GTP $\gamma$ S are given above the basal (taken to be $100 \%$ ) activity as a function of increasing concentrations $\left(10^{-10}-10^{-5} \mathrm{M}\right)$ of DAMGO, Ile ${ }^{5,6}$ deltorfin II and dynorphin ${ }_{1-13}$, a MOP, DOP and KOP receptors ligand, respectively. Points represent mean value \pm S.E.M. for three experiments performed in triplicate. The level of basal activity indicates constitutive G-protein activity in the absence of any stimulating ligand.

only on the contralateral thalamus in $\mathrm{CCl}$ mice (Fig. 4E). The GTP $\gamma$ S binding stimulated by dynorphin ${ }_{1-13}$ was similar in naïve mice (both parts) and in the ipsilateral part in $\mathrm{CCl}$-subjected mice, but it was weaker on the contralateral part of thalamus in $\mathrm{CCl}$ mice (Fig. 4F).

\section{DISCUSSION}

The present study assessed neuropathic pain-related behavioral changes accompanied by dynamic and specific alterations of opioid system gene expression levels and opioid receptor activity in the nociceptive neuronal structures, the spinal cord and thalamus. In the spinal cord, opioid peptide gene expression levels increased in the parts ipsilateral to the site of the injury. These changes were accompanied by tactile hypersensitivity that was most pronounced on day 14 .
These increases in opioid peptide gene expression may suggest the enhancement of peptidergic neuronal activity. Increase in the synthesis of opioid prohormones and the subsequent release of endogenous ligands, accompanied by a decrease in all MOP, DOP, KOP opioid receptor gene expression levels and decreased functional activity of these receptors, as examined by GTP $\gamma \mathrm{S}$ binding on day 14 (the chosen time point, when the strongest behavioral changes were observed), in the ipsilateral spinal cord and contralateral thalamus in a mouse model of neuropathic pain were demonstrated. These results are in agreement with other studies that described significantly decreased density of MOP receptor immunoreactivity in the dorsal horn of the spinal cord in a rat model of neuropathic pain (Kohno et al., 1999; Zöllner et al., 2003), suggesting a link to reduced opioid analgesia.

The view is now accepted that there is a loss in spinal opioid responsiveness under neuropathy (Cahill et al., 2003). It has been shown that phosphorylated-MOP receptor-like immunoreactivity is increased on the ipsilateral side in the superficial laminae of the L5 lumbar spinal dorsal horn after sciatic nerve-ligation in mice; the authors conclude that this, at least in part, contributes to the reduction in the antinociceptive effect produced by morphine (Narita et al., 2004). Other studies have shown significantly decreased density of MOP receptor immunoreactivity in the dorsal horn of the spinal cord in a rat model of neuropathic pain (Kohno et al., 1999; Zöllner et al., 2003), suggesting a link to reduced opioid analgesia. Opioids injected intrathecally activate spinal pre- and postsynaptic opioid receptors, of which 50 to $70 \%$ are presynaptically located on primary afferents (Gouardères et al., 1991; Abbadie et al., 2002). Neuropathy induced by peripheral nerve injury has been shown to cause profound reorganization of the nociceptive circuits within the spinal cord and the brain, including changes in gene expression and morphology (Mayer et al., 1999; Ossipov et al., 2000; Przewlocki and Przewlocka, 2001). However, the basis for the lack of opioid efficacy remains unclear. In 1999, Kohno et al. indicated that nerve damage negatively influences the action of MOP receptor agonists; the pre- and postsynap- 
tic inhibition of excitatory postsynaptic currents, caused normally by such agonists, is less effective under nerve injury conditions. The hyperexcitability of spinal neurons with unilateral changes in opioid system activity is transmitted to the thalamus under neuropathic conditions. The ventral posterior thalamus is the major termination site for the spinothalamic tract, and it relays nociceptive activity to the somatosensory cortex. During neuropathic pain, changes in neuronal firing in characteristic groups of neurons occur (Patel and Dickenson, 2016). Changes in endogenous opioid system activity in this structure may be very important for the final feeling of pain.

In recent years, several papers have identified an asymmetric distribution of opioid receptors and their endogenous ligands after traumatic brain injury (Bakalkin et al., 1982; Bakalkin and Kobylyansky, 1989; Bakalkin, 1989; Hussain et al., 2012). Unilateral changes in opioid receptor binding were also observed in chronic pain patients with central post-stroke pain, which was considered to reflect a sustained increase in the release of endogenous opioids. In those patients, interhemispheric comparisons using positron-emission tomography demonstrated a significant decrease in $\left[{ }^{11 \mathrm{C}}\right.$ ]diprenorphine binding in the posterior midbrain, medial thalamus and the insular, temporal and prefrontal cortices contralateral to the painful side (Maarrawi et al., 2007a,b). Our observation of MOP receptor changes in the spinal cord and thalamus support and supplement the above information with results in the animal model; furthermore, they extend this clinical observation with information on changes in other opioid receptors. In our study, KOP receptor mRNA levels significantly decreased on day 14 in the ipsilateral part of the spinal cord and contralateral part of the thalamus. Interestingly, the study of Xu et al. (2004) indicates that, in contrast to our results, KOP immunoreactivity was markedly increased in the L4-L5 spinal dorsal horn of C57BL/6 mice 7-21 days after injury but not in mice pretreated with the KOP antagonist nor-binaltorphimine (norBNI). On the other hand, in 2003, we showed (Obara et al., 2003) that the administration of KOP receptor antagonists norBNI and $5^{\prime}$-guanidinonaltrindole (GNTI) enhanced pain in rats and mice in a $\mathrm{CCl}$ model of neuropathic pain. The hypersensitivity potentiation after norBNI or GNTI administration was inhibited by the earlier administration of dynorphin antibody or ketamine. Our results suggest that enhanced sensitivity is mediated through non-opioid effects of the endogenous opioid peptide, dynorphin. The spinal release of PDYN-derived ligands after nerve injury is known to contribute to neuropathic pain development (Obara et al., 2003; Labombarda et al., 2008; Mika et al., 2010; Chen et al., 2014; Rojewska et al., 2014). Their non-opioid action is potentiated by the blockade of KOP receptors; this finding corresponds with the elevation of PDYN mRNA levels in the ipsilateral part of the spinal cord in our experiments. In addition, knock-out mice lacking PDYN, KOP, or Gprotein receptor kinase 3 did not show significant increases in KOP immunoreactivity after spinal nerve ligation. KOP knock-out mice developed significantly increased tactile and thermal hypersensitivity in both the early (first week) and late (third week) intervals after injury. It has been suggested that endogenous dynorphin has both pronociceptive and antinociceptive actions after nerve injury (Xu et al., 2004; Rojewska et al., 2014). The dynorphin also acted as an endogenous agonist at KOP receptors. Numerous studies have documented the antinociceptive effects of the intrathecal and systemic administration of selective KOP agonists (Nakazawa et al., 1991; Kolesnikov et al., 1996; Obara et al., 2003; Rojewska et al., 2014). Thus, the endogenous opioids derived from PDYN may have both antinociceptive and pronociceptive actions. It is not clear how the sustained activation of opioid receptors caused by endogenous dynorphin contributes to the neuropathic pain state; as the dynorphin level is higher in neuropathy than in physiological conditions, it is probably that it may be able to activate potentially pronociceptive receptors (such as NMDA and bradykinin receptors) after the saturation of KOP receptors (Vanderah et al., 1996; Obara et al., 2003; Rojewska et al., 2014). Furthermore, KOP receptor functional activity is weaker, as was shown in our study with GTP $\gamma S$ binding. The lower functional activity of KOP receptors might shift the balance from antinociceptive to pronociceptive actions of the endogenous dynorphin system and thus contribute to the weakening of the effects of opioid drugs in neuropathic pain.

Changes in the DOP receptor mRNA expression show lateralized and functional changes that differed depending on the structure. DOP receptor mRNA level decreased in the ipsilateral part of the spinal cord on the 14th day, while in the thalamus, a decrease was observed in the same time point but only on the contralateral side. The changes in functional activity measured by GTP $\gamma \mathrm{S}$ binding showed differences depending on the structure. In the thalamus, a potent contralateral decrease in expression was accompanied by a very dynamic difference in functional GTP $\gamma \mathrm{S}$ binding to DOP receptors in a wide range of doses. The described strong contralateral changes in the thalamic pain pathways, occurring in all opioid receptors in both their expression and GTP $\gamma S$ binding, may reduce the effect of opioid drugs in this kind of pain, but this aspect requires further research.

In contrast, in the spinal cord, the significant decrease in the ipsilateral level of DOP receptor mRNA was accompanied by a slight, much less pronounced than for MOP and KOP, decrease in GTP $\gamma S$ binding to this receptor. Interestingly, Obara et al. (2009) used an $E_{50}$ analysis to demonstrate that much higher doses of MOP and KOP agonists injected intraplantarly are required to produce analgesia in neuropathic versus inflammatory pain; in contrast, the $\mathrm{ED}_{50}$ of DOP agonists is comparable in both models of chronic pain. Many studies have shown that selective DOP agonists do not lose their effectiveness in neuropathic pain (Mika et al., 2001, 2014; Gavériaux-Ruff and Kieffer, 2011).

Our experiments show that changes in GTP $\gamma \mathrm{S}$ binding are similar between spinal and thalamic MOP/KOP receptors, whereas the activation of DOP receptors is remarkably different in both structures studied. In the spinal cord, the difference in opioid ligand stimulation of DOP receptors was minimal, while in the thalamus, the 
binding level on the contralateral side dropped significantly for a wide range of doses.

The spinal differences in GTP $\gamma \mathrm{S}$ binding of MOP and KOP receptors compared to DOP receptors are in agreement with our previous behavioral studies. Mika et al. (2014) showed that selective agonists of MOP and KOP receptors (DAMGO and $\mathrm{U} 50,488 \mathrm{H}$, respectively), in contrast to DOP receptor agonists (DPDPE, deltorphin II or SNC80), lose their analgesic effectiveness after nerve injury. Our preliminary data performed in the $\mathrm{CCl}$ model on mice on day 14 after injury indicate a lower ED50 for morphine given i.th. in comparison to naive animals ( $1.25 \mathrm{~g}$ vs $2.9 \mathrm{~g}$, respectively), while the ED50 for enkephalin is very close to the values obtained in naive mice $(0.03 \mathrm{~g}$ vs $0.05 \mathrm{~g}$, respectively). We suggest that this difference may be related to the fact that DOP analgesia is not dependent on injury-induced microglial activation. Our in vitro study (Mika et al., 2014) confirmed the presence of MOP/KOP receptors and the concurrent absence of DOP receptors in microglial cells. This is in agreement with other studies that have shown that microglia express MOP and KOP receptors (Chang et al. 1996; El-Hage et al. 2013; Merighi et al. 2013). Chao et al. (1996) first reported in 1996 that KOP receptors are present in human microglia, and the expression was confirmed by the membrane binding of the selective ligand $\left[{ }^{3} \mathrm{H}\right]$ U69,593. Thus, a slight change in GTP $\gamma \mathrm{S}$ binding of DOP ligands in the mouse $\mathrm{CCl}$ model in our studies may explain this lack of change in the analgesic response of these ligands after their spinal or peripheral administration compared to the attenuated MOP and KOP efficiency. However, in the thalamus, we demonstrated a very strong reduction in the GTP $\gamma S$ binding of this receptor. This change may be important in reducing the central effect of opioid drugs that have an MOP/DOP activity profile. The functional state of the MOP receptor is known to be dependent on the DOP receptor (Scherrer et al., 2009), and the strong weakening of the binding of these two receptors in the structures important for the central effects of opioid drugs can have a large impact on the analgesic effect of opioid drugs in neuropathic pain.

\section{SUMMARY}

Activity of opioid systems is altered by neuropathy development, which induces an increase in endogenous opioid peptide availability, which consequently results in transiently enhanced opioid receptor occupancy leading to a likely decrease in receptor expression. Our studies provide evidence for selective changes in the activity of spinal and thalamic opioid systems in a mouse neuropathic pain model. Our experiments show that similar changes in the GTP $\gamma S$ binding of MOP and KOP receptors occurred in the spinal cord and thalamus, whereas the binding to the DOP receptor was very different depending on the structure. At the spinal cord level, the difference in ligand binding to the DOP receptor was minimal which may explain the lack of lower efficacy of DOP receptor ligands after their i.th. or i.pl. administration in neuropathic pain model. However, strong reduction in the thalamic GTP $\gamma S$ binding may be the cause of reduced central effect of opioid drugs with MOP/DOP efficacy in neuropathic pain.

UNCITED REFERENCE

Xanthos et al. (2011).

\section{CONFLICT OF INTEREST}

None to disclose.

\section{ACKNOWLEDGMENTS}

This study was supported by the National Science Centre, Poland, grant MAESTRO 2012/06/A/NZ4/00028 and statutory funds from the Institute of Pharmacology at the Polish Academy of Sciences and European Commission, FP7 (\#HEALTH-F2-2013-602891); J.S. is a holder of a KNOW scholarship sponsored by the Ministry of Science and Higher Education, Poland. The work (E.S. and S.B.) was supported by the Polish (PAN) and Hungarian (MTA) Academy of Sciences, which provided bilateral researcher exchange programmes.

\section{REFERENCES}

Abbadie C, Lombard MC, Besson JM, Trafton JA, Basbaum AI (2002) $\mathrm{Mu}$ and delta opioid receptor-like immunoreactivity in the cervical spinal cord of the rat after dorsal rhizotomy or neonatal capsaicin: an analysis of pre- and postsynaptic receptor distributions. Brain Res 15:150-162.

Albe-Fessard D, Berkley KJ, Kruger L, Ralston 3rd HJ, Willis Jr WD (1985) Diencephalic mechanisms of pain sensation. Brain Res 356:217-296.

Bakalkin GYA (1989) Neuropeptides induce directional asymmetry in brain and spinal cord: facts and hypotheses. Int $\mathrm{J}$ Neurosci 48:105-124.

Bakalkin GYA, Kobylyansky AG (1989) Opioids induce postural asymmetry in spinal rat: the side of the flexed limb depends upon the type of opioid agonist. Brain Res 20:277-289.

Bakalkin GYA, Krivosheev OG, Stolyarov GK (1982) Postural asymmetry in rats induced by stress and pain stimuli. Life Sci 30:779-783.

Bencherif B, Fuchs PN, Sheth R, Dannals RF, Campbell JN, Frost JJ (2002) Pain activation of human supraspinal opioid pathways as demonstrated by [11C]-carfentanil and positron emission tomography (PET). Pain 99:589-598.

Bennett GJ, Xie YK (1988) A peripheral mononeuropathy in rat that produces disorders of pain sensation like those seen in man. Pain 33:87-107

Bradford MM (1976) Rapid and sensitive method for the quantitation of microgram quantities of protein utilizing the principle of proteindye binding. Anal Biochem 72:248-254.

Cahill CM, Dray A, Coderre TJ (2003) Intrathecal nerve growth factor restores opioid effectiveness in an animal model of neuropathic pain. Neuropharmacology 45:543-552.

Chang AC, Chao CC, Takemori AE, Gekker G, Hu S, et al. (1996) Arylacetamide-derived fluorescent probes: synthesis, biological evaluation, and direct fluorescent labeling of kappa opioid receptors in mouse microglial cells. J Med Chem 39:1729-1735.

Chao CC, Gekker G, Hu S, Sheng WS, Shark KB, Bu DF, Archer S, Bidlack JM, Peterson PK (1996) Kappa opioid receptors in human microglia downregulate human immunodeficiency virus 1 expression. Proc Natl Acad Sci USA 23:8051-8056.

Chen X, Wang T, Lin C, Chen B (2014) Effect of adenoviral delivery of prodynorphin gene on experimental inflammatory pain induced by formalin in rats. Int J Clin Exp Med 7:4877-4886.
724 
Chomczynski P, Sacchi N (1987) Single-step method of RNA isolation by acid guanidinium thiocyanate-phenol-chloroform extraction. Anal Biochem 162:156-159.

El-Hage N, Dever SM, Podhaizer EM, Arnatt CK, Zhang Y, et al. (2013) A novel bivalent HIV-1 entry inhibitor reveals fundamental differences in CleiCR5- $\mu$-opioid receptor interactions between human astroglia and microglia. AIDS 27:2181-2190.

Gavériaux-Ruff C, Kieffer BL (2011) Delta opioid receptor analgesia: recent contributions from pharmacology and molecular approaches. Behav Pharmacol 22:405-414.

Gouardères C, Beaudet A, Zajac JM, Cros J, Quirion R (1991) High resolution radioautographic localization of [125I]FK-33-824labelled mu opioid receptors in the spinal cord of normal and deafferented rats. Neuroscience 43:197-209.

Henderson LA, Peck CC, Petersen ET, Rae CD, Youssef AM, Reeves JM, Wilcox SL, Akhter R, Murray GM, Gustin SM (2013) Chronic pain: lost inhibition? J Neurosci 33:7574-7582.

Hussain ZM, Fitting S, Watanabe H, Usynin I, Yakovleva T, Knapp PE, Scheff SW, Hauser KF, Bakalkin G (2012) Lateralized response of dynorphin a peptide levels after traumatic brain injury. J Neurotrauma 29:1785-1793.

ladarola MJ, Brady LS, Draisci G, Dubner R (1988) Enhancement of dynorphin gene expression in spinal cord following experimental inflammation: stimulus specificity, behavioral parameters and opioid receptor binding. Pain 35:313-326.

Kohno TE, Kumamoto Higashi H, Shimoji K, Yoshimura M (1999) Actions of opioids on excitatory and inhibitory transmission in substantia gelatinosa of adult rat spinal cord. J Physiol 518:803-813.

Kolesnikov Y, Jain S, Wilson R, Pasternak GW (1996) Peripheral kappa 1-opioid receptor-mediated analgesia in mice. Eur $\mathrm{J}$ Pharmacol 310:141-143.

Labombarda F, Coronel MF, Villar MJ, Nicola AF, González SL (2008) Neuropathic pain and temporal expression of preprodynorphin, protein kinase $\mathrm{C}$ and $\mathrm{N}$-methyl-D-aspartate receptor subunits after spinal cord injury. Neurosci Lett 12:115-119.

Leite-Almeida H, Guimarães MR, Cerqueira JJ, Ribeiro-Costa N, Anjos-Martins H, Sousa N, Almeida A (2014) Asymmetric c-fos expression in the ventral orbital cortex is associated with impaired reversal learning in a right-sided neuropathy. Mol Pain 2:10-41.

Maarrawi J, Peyron R, Mertens P, Costes N, Magnin M, Sindou M, Laurent B, Garcia-Larrea L (2007a) Motor cortex stimulation for pain control induces changes in the endogenous opioid system. Neurology 28:827-834

Maarrawi J, Peyron R, Mertens P, Costes N, Magnin M, Sindou M, Laurent B, Garcia-Larrea L (2007b) Differential brain opioid receptor availability in central and peripheral neuropathic pain. Pain 127:183-194.

Mayer DJ, Mao J, Holt J, Price DD (1999) Cellular mechanisms of neuropathic pain, morphine tolerance, and their interactions. Proc Natl Acad Sci USA 96:7731-7736.

Merighi S, Gessi S, Varani K, Fazzi D, Stefanelli A, et al. (2013) Morphine mediates a proinflammatory phenotype via $\mu$-opioid receptor-PKC $\varepsilon$-Akt-ERK1/2 signaling pathway in activated microglial cells. Biochem Pharmacol 86:487-496.

Mika J, Jurga AM, Starnowska J, Wasylewski M, Rojewska E, Makuch W, Kwiatkowski K, Malek N, Przewlocka B (2015) Effects of chronic doxepin and amitriptyline administration in naïve mice and in neuropathic pain mice model. Neuroscience 294:38-50.

Mika J, Popiolek-Barczyk K, Rojewska E, Makuch W, Starowicz K, Przewlocka B (2014) Delta-opioid receptor analgesia is independent of microglial activation in a rat model of neuropathic pain. PLoS One 9(8):e104420.

Mika J, Przewlocki R, Przewlocka B (2001) The role of delta-opioid receptor subtypes in neuropathic pain. Eur J Pharmacol 9:31-37.

Mika J, Rojewska E, Makuch W, Przewlocka B (2010) Minocycline reduces the injury-induced expression of prodynorphin and pronociceptin in the dorsal root ganglion in a rat model of neuropathic pain. Neuroscience 17:1420-1428.
Nakazawa T, Furuya Y, Kaneko T, Yamatsu K (1991) Spinal kappa receptor-mediated analgesia of E-2078, a systemically active dynorphin analog, in mice. J Pharmacol Exp Ther 256:76-81.

Narita M, Kuzumaki N, Suzuki M, Narita M, Oe K, Yamazaki M, Yajima Y, Suzuki T (2004) Increased phosphorylated-mu-opioid receptor immunoreactivity in the mouse spinal cord following sciatic nerve ligation. Neurosci Lett 9:148-152.

Narita M, Ozaki S, Suzuki T (2002) Endomorphin-induced motivational effect: differential mechanism of endomorphin-1 and endomorphin-2. Jpn J Pharmacol 89:224-228.

Obara I, Gunduz Cinar O, Starowicz K, Benyhe S, Borsodi A, Przewlocka B (2010) Agonist-dependent attenuation of mu-opioid receptor-mediated G-protein activation in the dorsal root ganglia of neuropathic rats. J Neural Transm (Vienna) 117:421-429.

Obara I, Mika J, Schafer MK, Przewlocka B (2003) Antagonists of the kappa-opioid receptor enhance allodynia in rats and mice after sciatic nerve ligation. Br J Pharmacol 140:538-546.

Obara I, Parkitna JR, Korostynski M, Makuch W, Kaminska D, Przewlocka B, Przewlocki R (2009) Local peripheral opioid effects and expression of opioid genes in the spinal cord and dorsal root ganglia in neuropathic and inflammatory pain. Pain 141:283-291.

Ossipov MH, Lai J, Malan Jr TP, Porreca F (2000) Spinal and supraspinal mechanisms of neuropathic pain. Ann NY Acad Sci 909:12-24.

Palkovits M, Brownstein MJ (1987) Maps and guide to microdissection of the rat brain. New York: Elsevier.

Patel R, Dickenson AH (2016) Neuronal hyperexcitability in the ventral posterior thalamus of neuropathic rats: modality selective effects of pregabalin. J Neurophysiol 116:159-170.

Popiolek-Barczyk K, Rojewska E, Jurga AM, Makuch W, Zador F, Borsodi A, Piotrowska A, Przewlocka B, Mika J (2014) Minocycline enhances the effectiveness of nociceptin/orphanin FQ during neuropathic pain. Biomed Res Int. 762930.

Przewlocki R, Przewlocka B (2001) Opioids in chronic pain. Eur J Pharmacol 429:79-91.

Rojewska E, Makuch W, Przewlocka B, Mika J (2014) Minocycline prevents dynorphin-induced neurotoxicity during neuropathic pain in rats. Neuropharmacology 86:301-310.

Rojewska E, Piotrowska A, Makuch W, Przewlocka B, Mika J (2016) Pharmacological kynurenine 3-monooxygenase enzyme inhibition significantly reduces neuropathic pain in a rat model. Neuropharmacology 102:80-91.

Scherrer G, Imamachi N, Cao YQ, Contet C, Mennicken F, O'Donnell D, Kieffer BL, Basbaum Al (2009) Dissociation of the opioid receptor mechanisms that control mechanical and heat pain. Cell 12:1148-1159

Szücs E, Büki A, Kekesi G, Horvath G, Benyhe S (2016) Mu-Opioid (MOP) receptor mediated G-protein signaling is impaired in specific brain regions in a rat model of schizophrenia. Neurosci Lett 619:29-33.

Traynor JR, Nahorski SR (1995) Modulation by mu-opioid agonists of guanosine- $5^{\prime}-\mathrm{O}-\left(3-\left[{ }^{35} \mathrm{~S}\right]\right.$ thio $)$-triphosphate binding to membranes from human neuroblastoma SH-SY5Y cells. Mol Pharmacol 47:848-854.

Vanderah TW, Laughlin T, Lashbrook JM, Nichols ML, Wilcox GL, Ossipov MH, Malan Jr TP, Porreca F (1996) Single intrathecal injections of dynorphin $A$ or des-Tyr-dynorphins produce longlasting allodynia in rats: blockade by MK-801 but not naloxone. Pain 68:275-281.

Xanthos DN, Gaderer S, Drdla R, Nuro E, Abramova A, Ellmeier W, Sandkühler J (2011) Central nervous system mast cells in peripheral inflammatory nociception. Mol Pain 3:7-42.

Xiao W, Naso L, Bennett GJ (2008) Experimental studies of potential analgesics for the treatment of chemotherapy-evoked painful peripheral neuropathies. Pain Med 9:505-517.

Xu M, Petraschka M, McLaughlin JP, Westenbroek RE, Caron MG, Lefkowitz RJ, Czyzyk TA, Pintar JE, Terman GW, Chavkin C (2004) Neuropathic pain activates the endogenous kappa opioid system in mouse spinal cord and induces opioid receptor tolerance. J Neurosci 12:4576-4584. 
Zangen A, Herzberg U, Vogel Z, Yadid G (1998) Nociceptive stimulus induces release of endogenous beta-endorphin in the rat brain. Neuroscience 85:659-662.

Zhang X, Bao L, Shi TJ, Ju G, Elde R, Hökfelt T (1998) Downregulation of mu-opioid receptors in rat and monkey dorsal root ganglion neurons and spinal cord after peripheral axotomy. Neuroscience 82:223-240.

Zimmermann M (1983) Ethical guidelines for investigations of experimental pain in conscious animals. Pain 16:109-110.
Zöllner C, Shaqura MA, Bopaiah CP, Mousa S, Stein C, Schafer M (2003) Painful inflammation-induced increase in mu-opioid receptor binding and G-protein coupling in primary afferent neurons. Mol Pharmacol 64:202-210.

Zubieta JK, Smith YR, Bueller JA, Xu Y, Kilbourn MR, Jewett DM, Meyer CR, Koeppe RA, Stohler CS (2001) Regional mu opioid receptor regulation of sensory and affective dimensions of pain. Science 13:311-315.

(Received 31 December 2017, Accepted 10 August 2018)

(Available online $x x x x$ ) 